\title{
Urea Metabolism in Chronic Renal Failure
}

\author{
MACKENZIE WALSER \\ From the Departments of Pharmacology and Experimental Therapeutics and \\ Medicine, Johns Hopkins University School of Medicine, \\ Baltimore, Maryland 21205
}

\begin{abstract}
A B S T R A C T Urea degradation was measured during 16 experiments in 13 chronic uremic patients being treated with essential amino acids or their analogues. $\left[{ }^{14} \mathrm{C}\right]$ Urea was injected i.v. and the clearance of labeled urea from its volume of distribution was compared with the simultaneous renal clearance of ordinary urea, which averaged 2.0 liters/day. The difference, extrarenal clearance of urea, averaged 3.1 liters/day as compared with a previously reported mean of 18 liters/day in normal subjects. Thus urea-splitting activity in the gut of uremic subjects expressed in these terms is far less than in normal individuals. Nevertheless, the amount of ammonia $\mathrm{N}$ formed from urea in these patients, $3.5 \mathrm{~g} /$ day, is not significantly different from normal, owing to their elevated plasma urea. In the same subjects, urea appearance rate was measured as the sum of urea excretion and the daily change in the urea pool. No negative correlation was noted between urea appearance and urea degradation, as might be expected if portal ammonia were being utilized for protein synthesis. However, urea production was positively correlated $(r=$ 0.76) with urea degradation, suggesting that most of the resulting portal ammonia is converted back to urea. The results fail to support the view that degradation of urea in the gut promotes $\mathrm{N}$ conservation in uremic subjects maintained on low protein diets.
\end{abstract}

\section{INTRODUCTION}

In normal subjects, the rate of urea breakdown in the gastrointestinal tract is about one-fourth its excreted rate $(1,2)$. The ammonia thus formed is largely reincorporated into urea in the liver, although some exchange of ${ }^{15} \mathrm{~N}$-labeled ammonia with amino acid nitrogen occurs (3). In uremia, the combined effects of reduced renal clearance and increased plasma concentration of urea might easily result in an increase in urea break-

\footnotetext{
Received for publication 29 October 1973 and in revised form 17 December 1973.
}

The Journal of Clinical Investigation Volume 53 May 1974-1385-1392

down, both in absolute terms and as a fraction of urea produced. Available evidence indicates that this does indeed occur $(2,4-8)$.

When dietary protein is restricted, this influx of portal ammonia could promote nitrogen conservation, as has been suggested (8-11). In diets containing essential amino acids but little or no nonessential nitrogen, ammonia nitrogen could be utilized for synthesis of nonessential amino acids. In diets containing nitrogen-free analogues of essential amino acids ( $\alpha$-ketoacids or $\alpha$-hydroxyacids) portal ammonia could be used to convert these analogues to essential amino acids. In either case, the rate of appearance of urea (measured as the sum of urea excretion and the change in the urea pool) should be low under such circumstances, because much of the urea produced by the liver would be used synthetically.

Thus intestinal degradation of urea may be beneficial to the uremic subject maintained on a low protein diet. On the other hand, the quantity of ammonia released into the portal circulation could be far in excess of the daily requirements for synthesis of amino acids. For example, one uremic patient I studied apparently degraded $17 \mathrm{~g}$ urea $\mathrm{N}$ daily (8), and two subjects studied by Jones, Smallwood, Craigie, and Rosenoer (2) were both found to degrade $15 \mathrm{~g}$ daily.

Continual breakdown of a major portion of synthesized urea is energetically wasteful. Furthermore, continued influx of such large amounts of ammonia into the liver might induce metabolic derangements.

The present studies were undertaken to determine the extent of urea degradation in severely uremic patients being maintained on low protein intakes, supplemented by essential amino acids or their keto- or hydroxyanalogues.

\section{METHODS}

On a total of 16 occasions, 13 subjects with severe chronic uremia were studied. Renal clearance of urea averaged 2.0 
ABLE I

Comparison of Logarithmic Slope of Plasma Disappearance of $\left[{ }^{14} \mathrm{C}\right]$ Urea and of Total ${ }^{14} \mathrm{C}$ after $\left[{ }^{14} \mathrm{C}\right]$ Urea Injection

\begin{tabular}{|c|c|c|c|}
\hline Subject & $\begin{array}{l}{\left[{ }^{14} \mathrm{C}\right] \text { Urea }} \\
\text { slope }\end{array}$ & $\begin{array}{l}{ }^{14} \mathrm{C} \\
\text { slope }\end{array}$ & $\begin{array}{c}\text { Ratio } \\
{\left[{ }^{14} \mathrm{C}\right] \text { Urea } /{ }^{14} \mathrm{C}}\end{array}$ \\
\hline $\begin{array}{l}\text { I. C. } \\
\text { G. M. } \\
\text { H. B. } \\
\text { J. H. } \\
\text { M. F. } \\
\text { J. W. }\end{array}$ & $\begin{array}{l}-0.160 \pm 0.022 \\
-0.222 \pm 0.014 \\
-0.148 \pm 0.020 \\
-0.078 \pm 0.036 \\
-0.162 \pm 0.017 \\
-0.063 \pm 0.030\end{array}$ & $\begin{array}{l}-0.157 \pm 0.012 \\
-0.218 \pm 0.022 \\
-0.149 \pm 0.010 \\
-0.072 \pm 0.011 \\
-0.159 \pm 0.034 \\
-0.062 \pm 0.009\end{array}$ & $\begin{array}{l}1.019 \\
1.018 \\
0.993 \\
1.083 \\
1.019 \\
1.016\end{array}$ \\
\hline & & $\begin{array}{l}\text { Mean } \\
\text { SEM }\end{array}$ & $\begin{array}{r}1.025 \\
\pm 0.012\end{array}$ \\
\hline
\end{tabular}

liters/day (range: 0-5.5 liters/day). All were studied under metabolic balance conditions on an approximately constant nitrogen intake, as described previously (12). Net $\mathrm{N}$ intake, defined as total intake minus urinary protein $\mathrm{N}$, averaged $2.16 \mathrm{~g} /$ day. Plasma creatinine averaged $18.1 \mathrm{mg} / 100 \mathrm{ml}$; plasma $\mathrm{CO}_{2}$ averaged $23 \mathrm{mM}$. None of these parameters differed significantly between the patients receiving amino acid supplements and those receiving keto- or hydroxyacid supplements. At the time of $\left[{ }^{14} \mathrm{C}\right]$ urea injections, essential amino acid supplements were being administered daily in six studies, and keto- or hydroxy-analogues of five essential amino acids plus the four remaining essential amino acids in the other 10 studies.

$\left[{ }^{14} \mathrm{C}\right]$ Urea (New England Nuclear Corp., Boston, Mass.) was dissolved in ethanol and kept at $-20^{\circ} \mathrm{C}$ until use. A portion was tested for sterility and pyrogenicity. Approximately $0.2 \mathrm{ml}$ of the ethanolic solution, containing approximately $12 \mu \mathrm{Ci}\left[{ }^{14} \mathrm{C}\right]$ urea, was diluted to $30 \mathrm{ml}$ with isotonic saline. Exactly $25 \mathrm{ml}$ of this solution was injected i.v. in the morning and the remainder was used for analysis. Blood samples were obtained $2 \mathrm{~h}$ later and each subsequent morning for a period of 4-11 days.

Daily 24-h urea excretion and plasma urea were measured throughout the study, and urea pool was calculated as previously described (12). The rate of change of the urea pool was calculated from the linear regression of urea pool on time during the period of observation. Urea appearance, $U$, was calculated as the algebraic sum of the daily change in urea pool and the mean rate of urinary urea excretion. Water content of plasma was assumed to be $95 \%$.

$\left[{ }^{14} \mathrm{C}\right]$ Urea in plasma was determined by the method previously described, with modifications (1). In each sample, ${ }^{14} \mathrm{C}$ was also measured directly in plasma, by use of NCS solubilizer (Nuclear-Chicago Corp., Des Plaines, Ill.) In both methods, aliquots of the injected solution were used for internal standardization. It soon became apparent that both methods yielded the same results. This is to be expected, since ${ }^{14} \mathrm{CO}_{2}$ formed from urea degradation should be excreted far more rapidly than urea itself in these patients. Incorporation of $\left[{ }^{14} \mathrm{C}\right]$ urea into albumin was negligible, as shown by the absence of detectable radioactivity in dialyzed plasma obtained 1 wk after the injection of $\left[{ }^{14} \mathrm{C}\right]$ urea. Previous work has shown that no more than $2 \%$ of administered ${ }^{14} \mathrm{CO}_{3}$ is incorporated into urea (13-15). Furthermore, the logarithmic slopes of $\left[{ }^{14} \mathrm{C}\right]$ urea disappearance and ${ }^{14} \mathrm{C}$ disappearance were indistinguishable (Table
I). The accumulation of appreciable quantities of ${ }^{14} \mathrm{C}$ in forms other than urea would have led to a lesser slope of ${ }^{14} \mathrm{C}$ disappearance. In practice, results were calculated from either ${ }^{14} \mathrm{C}$ data or $\left[{ }^{14} \mathrm{C}\right]$ urea data, depending upon which gave narrower confidence limits (see below).

Urea kinetics in a "semi-steady" state. In normal subjects under ordinary circumstances, the urea pool changes little from day to day. Adjustment to altered nitrogen intake can be achieved within a few days. Thus a steady state of urea production and excretion is readily attained. In severe uremia, by contrast, the urea pool is rarely constant, because adjustment of excretion to an altered state of urea production may require weeks. The time constant of approach to a new steady state is roughly proportional to the urea clearance, which may be only a few percent of normal. Furthermore, because of the greatly enlarged urea pool, small fractional changes in this pool may constitute significant amounts of nitrogen. Hence any model of urea kinetics in uremia based on the steady-state assumption is inadequate. An alternative assumption is that the renal clearance $\left(C_{R}\right)$, extrarenal clearance $\left(C_{\boldsymbol{M}}\right)$, and appearance rate $(U)$ are constant. These are the parameters which determine the final steady-state value of the urea pool, but these quantities must remain constant for several weeks (in severe uremia) before the steady state is achieved. As shown below, methods for testing the validity of these assumptions in a given subject are available.

The concentration of $\left[{ }^{14} \mathrm{C}\right]$ urea in plasma water, $P^{\prime} / 0.95$, extrapolated to the time of injection, $P^{\prime}{ }_{0} / 0.95$ multiplied by the urea volume of distribution, $V$, is equal to the injected dose, $V P^{\prime}{ }_{o} / 0.95$. This is not true in normal subjects owing to "excess excretion" (1) during the period of equilibration, but this quantity is reduced in relation to the reduction of renal function and may therefore be ignored in severe uremia. Robson (4) measured excess excretion of $\left[{ }^{14} \mathrm{C}\right]$ urea in 23 studies in chronic uremia and found an average value of only $1.25 \%$ of the injected dose. The rate of removal

TABLE II

Original and Derived Data in a Representative Experiment

\begin{tabular}{ccccccc}
\hline & & \multicolumn{2}{c}{ Urea N } & & & \\
\cline { 3 - 6 } Day & & Wt & $\begin{array}{c}\text { Plasma, } \\
\text { [14C]Urea } \\
\text { Plasma, } \\
P^{\prime}\end{array}$ & $\begin{array}{c}\text { Urine, } \\
\text { Urea N } \\
\text { pool, } \\
V P / 0.95\end{array}$ & $\begin{array}{c}\text { Renal } \\
\text { clearance, } \\
C_{R}\end{array}$ \\
\hline & $k g$ & $g /$ liter & $g /$ day & $\mu C i /$ liter & $g$ & liter/day \\
1 & 83.5 & 0.89 & 3.31 & 0.216 & 42.38 & 3.53 \\
2 & 83.7 & 0.84 & 2.38 & 0.168 & 40.18 & 2.69 \\
3 & 83.65 & 0.75 & 2.61 & 0.161 & 35.83 & 3.31 \\
4 & 85.4 & 0.69 & 2.10 & 0.126 & 34.24 & 3.23 \\
5 & 83.5 & 0.70 & 2.46 & 0.111 & 33.34 & 3.33 \\
\hline
\end{tabular}

Regression of loge $\left(P^{\prime} / 0.95\right)$ on $t$ : slope, $k=-0.162 \pm 0.017$; intercept, $P_{\circ}^{\prime} / 0.95=0.221$.

$V=10^{*} /\left(P_{0}^{\prime} / 0.95\right)=45.24$ liter.

Regression of $V P$ on $t$ : slope, $\Delta=-2.40 \pm 0.03$; intercept, $V P_{o} / 0.95$ $=42.00$.

Total clearance $=V k=7.33(5.05-10.48) \ddagger$ liters $/$ day; Renal clearance $=R /(P / 0.95)=C_{R}=3.15 \pm 0.15$ liters $/$ day $;$ Extrarenal clearance $=C_{M}$ $=V k-C_{R}=4.18$ liters $/$ day; Mean $P=\bar{P}=0.77 \mathrm{~g} /$ liter; Mean excretion $=R=2.57 \mathrm{~g}$ N/day; Degradation $=\bar{M}=\mathrm{C}_{\boldsymbol{M}} \bar{P} / 0.95=3.39 \mathrm{~g}$ $\mathrm{N} /$ day; Appearance $=U=\bar{R}+\Delta=0.17 \mathrm{~g}$ N/day; Production $=\bar{A}$ $=U+\bar{M}=3.56 \mathrm{~g} \mathrm{~N} / \mathrm{day}$.

[14C] Urea was injected i.v. in subject M. F. on day 1

$*$ Injected dose in microcuries.

$\$ 95 \%$ confidence limits.

\section{M. Walser}




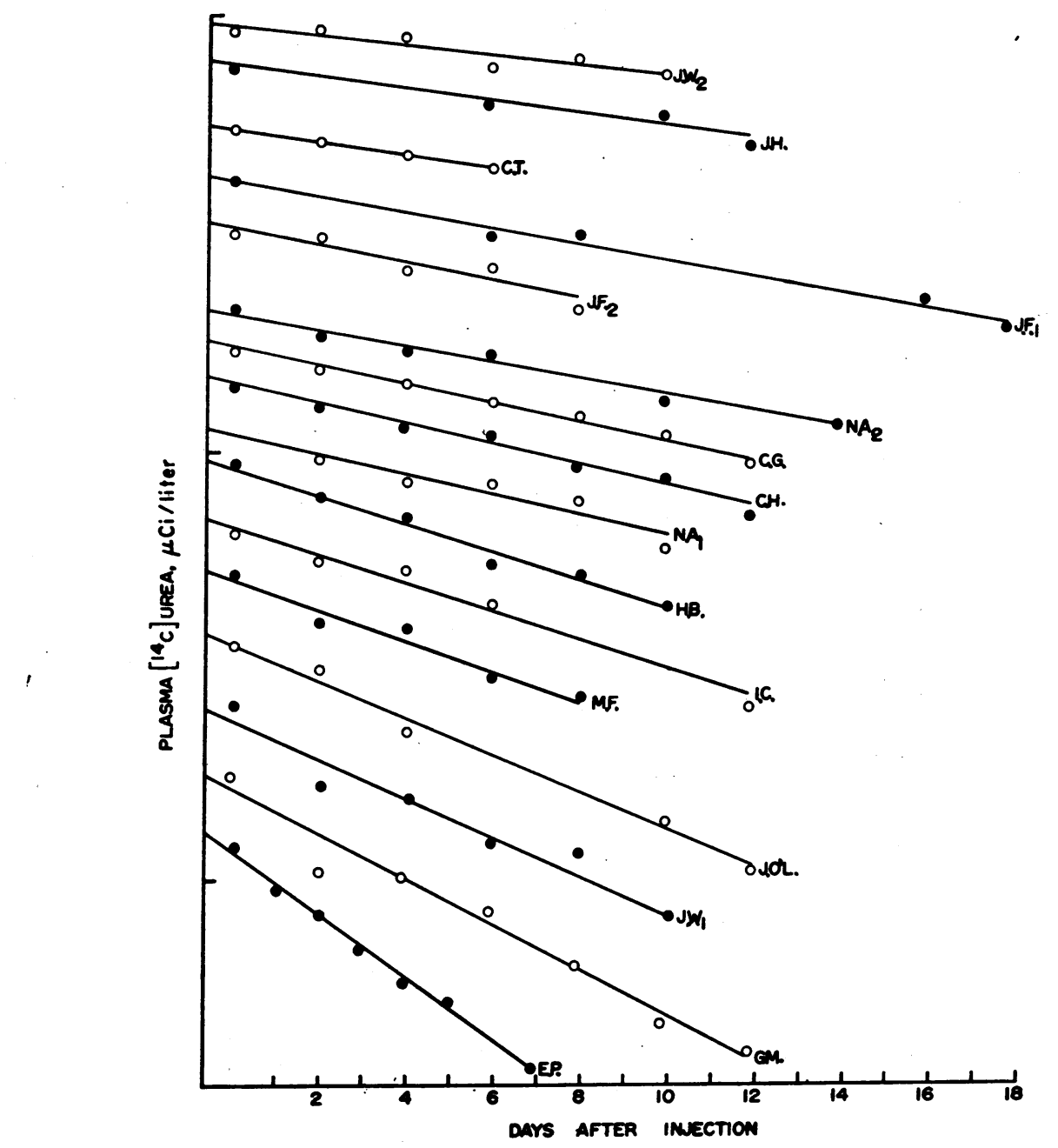

FIGURE 1 Plasma disappearance curves of $\left[{ }^{14} \mathrm{C}\right]$ urea in 16 studies. The first sample was obtained $2 \mathrm{~h}$ after injection. Results for each subject have been multiplied by constant factors chosen so that all 16 curves could be illustrated on the same plot. The ordinate is a uniform logarithmic scale, on which decades are indicated as horizontal marks.

by renal and extrarenal routes of $\left[{ }^{14} \mathrm{C}\right]$ urea, $\mathrm{d}\left(V P^{\prime} / 0.95\right) /$ $\mathrm{d} t$, is proportional to the plasma water concentration.

$$
\mathrm{d}\left(V P^{\prime} / 0.95\right) / \mathrm{d} t=-\left(C_{R}+C_{M}\right) P^{\prime} / 0.95
$$

If $V$ is constant, integration yields

where

$$
P^{\prime}=P^{\prime} e^{-k t} \text {, }
$$

$$
k=\left(C_{R}+C_{M}\right) / V .
$$

Total clearance, $C_{\boldsymbol{T}}\left(=C_{E}+C_{\mathbf{x}}\right)$ is thus obtained as $k V$. Confidence limits of $C_{T}$ are calculated as previously described (16) using a computer program. The rate of urinary excretion of ordinary urea, $R$, on any given day is defined by $C_{R}=R /(P / 0.95)$, and the rate of extrarenal disappearance, $M$, is defined by $C_{\mathbf{x}}=M /(P / 0.95) . C_{R}$ and $C_{\boldsymbol{x}}$ are assumed constant, although $R, M$, and $P$ may all be changing slightly from day to day. Thus $\bar{M}$ may be calculated as $\left(k V-C_{R}\right) \times(\bar{P} / 0.95)$.
Urea appearance rate, $U$, is defined by

$$
U=\bar{A}-\bar{M}
$$

where $\bar{A}$ is urea production (12). As noted above, $U$ is assumed to be constant during the period of observation. The average value of $M$ during the period of observation may therefore be added to the measured value of $U$ to obtain an estimate of $\bar{A}$. No estimate is obtained by these methods of the contribution of portal ammonia to urea production.

The implicit assumption is also made here that the renal and extrarenal clearances of labeled and unlabeled urea are the same. In normal subjects, specific activity of urinary urea slightly exceeds the specific activity of plasma urea (1). However; the explanation of this difference that has been generally accepted (17), namely that urine urea is in equilibrium with a substantial pool of urea in the kidney, is probably inapplicable in severe uremia. Robson (4) found 
TABLE III

Summary of Urea Metabolism Observations in Uremic Patients, Arranged in Order of Decreasing Renal Clearance

\begin{tabular}{|c|c|c|c|c|c|c|c|c|c|c|c|c|}
\hline & Wt & $\boldsymbol{V}$ & $\bar{P}$ & $\Delta$ & $k$ & $C_{T}$ & $C_{R}$ & $C_{M}$ & $\overline{\boldsymbol{R}}$ & $M$ & $U$ & $A$ \\
\hline & $k g$ & liter & g/liter & $g / d a y$ & $\begin{array}{l}\text { liters/ } \\
\text { day }\end{array}$ & $\begin{array}{l}\text { liters/ } \\
\text { day }\end{array}$ & $\begin{array}{l}\text { liters/ } \\
\text { day }\end{array}$ & $\begin{array}{l}\text { liters/ } \\
\text { day }\end{array}$ & $g / d a y$ & $g / d a y$ & $g / d a y$ & $g / d a y$ \\
\hline \multicolumn{13}{|c|}{ Patients receiving essential amino acids } \\
\hline E. $P$. & 59.9 & 30.6 & 1.44 & $-0.38 \pm 0.16$ & $-0.159 \pm 0.004$ & $\begin{array}{c}4.87 \\
(4.60-5.15)^{*}\end{array}$ & $5.25 \pm 0.21$ & 0.00 & 4.96 & 0.00 & 4.58 & 4.58 \\
\hline J. W.1 & 53.0 & 33.8 & 0.65 & $-0.32 \pm 0.29$ & $-0.205 \pm 0.026$ & $\begin{array}{c}6.88 \\
(4.54-8.78)^{*}\end{array}$ & $3.05 \pm 0.16$ & 3.83 & 2.04 & 2.62 & 1.72 & 4.34 \\
\hline H. B. & 75.9 & 45.6 & 1.07 & $-3.02 \pm 0.34$ & $-0.149 \pm 0.010$ & $\begin{array}{c}6.80 \\
(5.60-7.83)^{*}\end{array}$ & $2.63 \pm 0.17$ & 4.17 & 2.69 & 4.70 & -0.33 & 4.37 \\
\hline J. 0. & 60.1 & 35.1 & 0.82 & $-1.67 \pm 0.29$ & $-0.201 \pm 0.012$ & $\begin{array}{c}6.68 \\
(5.57-7.75) *\end{array}$ & $2.86 \pm 0.17$ & 3.82 & 2.46 & 3.30 & 0.79 & 4.09 \\
\hline N. A.1 & 72.6 & 28.0 & 1.40 & $-2.12 \pm 0.21$ & $-0.107 \pm 0.022$ & $\begin{array}{c}2.70 \\
(0.37-4.14)^{*}\end{array}$ & $0.87 \pm 0.11$ & 1.83 & 1.25 & 2.70 & -0.87 & 1.83 \\
\hline J. W.2 & 52.3 & 31.4 & 1.01 & $+1.16 \pm 0.40$ & $-0.062 \pm 0.009$ & $\begin{array}{c}1.95 \\
(0.97-2.78) *\end{array}$ & $0.00 \pm 0.00$ & 1.95 & 0.00 & 2.07 & 1.16 & 3.23 \\
\hline $\begin{array}{l}\text { Mean } \\
\text { SEM }\end{array}$ & & & $\begin{array}{r}1.06 \\
\pm 0.13\end{array}$ & $\begin{array}{l}-1.06 \\
\pm 0.61\end{array}$ & $\begin{array}{l}-0.147 \\
\pm 0.023\end{array}$ & $\begin{array}{r}4.98 \\
\pm 0.90\end{array}$ & $\begin{array}{r}2.36 \\
\pm 0.91\end{array}$ & $\begin{array}{r}2.60 \\
\pm 0.66\end{array}$ & $\begin{array}{r}2.23 \\
\pm 0.68\end{array}$ & $\begin{array}{r}2.56 \\
\pm 0.63\end{array}$ & $\begin{array}{r}1.18 \\
\pm 0.78\end{array}$ & $\begin{array}{r}3.74 \\
\pm 0.43\end{array}$ \\
\hline \multicolumn{13}{|c|}{ Patients receiving keto- or hydroxyacids } \\
\hline G. $\mathbf{M}$. & 66.6 & 47.0 & 1.12 & $-2.33 \pm 0.76$ & $-0.218 \pm 0.022$ & $\begin{array}{c}10.62 \\
(9.04-13.12) *\end{array}$ & $3.78 \pm 0.66$ & 6.84 & 4.29 & 8.06 & 1.96 & 10.02 \\
\hline C. H. & 68.2 & 39.6 & 1.70 & $-1.28 \pm 0.60$ & $-0.106 \pm 0.007$ & $\begin{array}{c}4.21 \\
(3.52-4.82)^{*}\end{array}$ & $3.15 \pm 0.18$ & 1.06 & 5.58 & 1.90 & 4.30 & 6.20 \\
\hline M. F. & 83.5 & 45.2 & 0.77 & $-2.40 \pm 0.03$ & $-0.162 \pm 0.017$ & $\begin{array}{c}7.33 \\
(5.05-10.48)^{*}\end{array}$ & $3.15 \pm 0.15$ & 4.18 & 2.57 & 3.39 & 0.17 & 3.56 \\
\hline I. $\mathrm{C}$. & 59.5 & 27.6 & 0.96 & $-0.58 \pm 0.13$ & $-0.157 \pm 0.012$ & $\begin{array}{c}4.78 \\
(3.57-5.83)^{*}\end{array}$ & $1.81 \pm 0.11$ & 2.97 & 1.82 & 3.00 & 1.24 & 4.24 \\
\hline C. G. & 67.9 & 43.2 & 1.00 & $-0.64 \pm 0.16$ & $-0.097 \pm 0.003$ & $\begin{array}{c}4.18 \\
(3.84-4.52) *\end{array}$ & $1.42 \pm 0.06$ & 2.76 & 1.47 & 2.91 & 0.83 & 3.74 \\
\hline N. A.2 & 74.4 & 30.1 & 0.87 & $-0.38 \pm 0.08$ & $-0.081 \pm 0.010$ & $\begin{array}{c}2.44 \\
(1.56-3.16) *\end{array}$ & $1.09 \pm 0.13$ & 1.35 & 0.98 & 1.24 & 0.60 & 1.84 \\
\hline J. H. & 78.5 & 59.8 & 1.28 & $+2.63 \pm 0.33$ & $-0.072 \pm 0.011$ & $\begin{array}{c}4.30 \\
(0.50-6.79) *\end{array}$ & $1.02 \pm 0.04$ & 3.28 & 1.38 & 4.42 & 4.01 & 8.43 \\
\hline J. F.1 & 79.6 & 81.5 & 1.68 & $-0.59 \pm 0.49$ & $-0.085 \pm 0.005$ & $\begin{array}{c}5.59 \\
(4.46-6.55) *\end{array}$ & $0.71 \pm 0.10$ & 4.88 & 1.27 & 8.63 & 0.68 & 9.31 \\
\hline C. T. & 56.3 & 33.8 & 1.95 & $0.00 \pm 0.32$ & $-0.071 \pm 0.003$ & $\begin{array}{c}2.45 \\
(1.85-3.02)^{*}\end{array}$ & $0.55 \pm 0.03$ & 1.90 & 1.09 & 3.90 & 1.09 & 4.99 \\
\hline J. F.2 & 78.0 & 83.7 & 0.69 & $+2.42 \pm 1.11$ & $-0.103 \pm 0.020$ & $\begin{array}{c}5.12 \\
(0.91-8.21)^{*}\end{array}$ & $0.44 \pm 0.12$ & 4.68 & 0.55 & 3.40 & 2.97 & 6.37 \\
\hline Mean & & & 1.20 & -0.32 & -0.115 & 5.10 & 1.71 & 3.39 & 2.10 & 4.08 & 1.79 & 5.87 \\
\hline SEM & & & \pm 0.14 & \pm 0.54 & \pm 0.015 & \pm 0.76 & \pm 0.39 & \pm 0.57 & \pm 0.51 & \pm 0.77 & \pm 0.47 & \pm 0.85 \\
\hline
\end{tabular}

Abbreviations used in this table: $V$, urea space; $\bar{P}$, mean plasma urea $\mathrm{N} ; \Delta$, rate of change of urea $\mathrm{N}$ pool $; k$, slope of plasma disappearance; $C_{T}$, total clearance; $C_{R}$, renal clearance; $C_{M}$, extrarenal clearance; $\bar{R}$, urinary excretion of urea $\mathrm{N} ; M$, extrarenal disappearance (degradation) of urea $\mathrm{N} ; U$, urea $\mathrm{N}$ appearance rate; $\bar{A}$, production rate of urea $\mathrm{N}$.

* $95 \%$ confidence limits.

the renal clearance of $\left[{ }^{14} \mathrm{C}\right]$ urea in chronic uremia to exceed the clearance of ordinary urea by only $2 \%$.

Tests are available for the assumptions of this model. (a) Conformity of the plasma decay curve for $\left[{ }^{14} \mathrm{C}\right]$ urea to a simple exponential function. (b) Constancy of daily measurements of ordinary urea clearance. (c) Linear rate of change of the urea pool over a time interval amounting to one half-life or more. Although none of these tests is rigorous, it is difficult to conceive how these conditions could all be met by any other model.

\section{RESULTS}

Data from a representative experiment are shown in Table II, which illustrates the method used in calculating the results.

The slope and intercept of the plasma $\left[{ }^{14} \mathrm{C}\right]$ urea decay curve are calculated by least squares regression. The intercept value gives the urea space, $V$. The product of $V$ and the slope yields the total clearance. The $95 \%$

\section{$1388 \quad$ M. Walser}


confidence limits are also shown. Note that they are not symmetrical.

From body weights, urea space, and plasma urea nitrogen concentrations, successive values of urea $\mathrm{N}$ pool are calculated as described previously (12). The rate of change of this pool, $\Delta$, is calculated by linear regression.

Renal clearance of urea is calculated for each $24-\mathrm{h}$ urine collection and averaged. Extrarenal clearance, $C \mathbf{x}$, is obtained by difference. The product of this quantity and average plasma urea $\mathrm{N}$ concentration gives $\bar{M}$, the rate of formation of ammonia $\mathrm{N}$ from urea degradation. Urea appearance rate, $U$, is calculated as the sum of average renal excretion and $\Delta$. Urea $N$ production is the algebraic sum of appearance and degradation.

The plasma disappearance curves for all of the experiments are shown in Fig. 1, and the calculated slopes and their standard errors are shown in Table III. It is apparent that the disappearance curves conform closely to simple exponential decay.

Despite the small standard errors of these slopes, the 95\% confidence limits of the calculated values for total clearance are rather wide (see Table III) in some experiments. Total clearance is calculated from the ratio of the slope to the intercept of the regression line, and therefore is subject to the variance of the intercept as well as the variance of the slope. The method of estimating confidence limits used here gives narrower limits than would conventional methods because it takes into account the strong correlation that generally exists between estimates of the slope and intercept.

Urea spaces in these subjects were consistent with anticipated body water in most cases. One patient (N. A.) had a urea space less than $40 \%$ of body weight. Nearly the same value was obtained on a second measurement. She was obese and had had a sedentary existence for years. Hence this value is not inconsistent with total body water. In subjects J. F., urea space exceeded body weight, corroborated by a second injection at a later date. This result implies that urea concentration intracellularly in some tissues must have been substantially higher than in plasma in this subject.

The half-life of $\left[{ }^{14} \mathrm{C}\right]$ urea was not significantly different between the two groups of patients studied, and averaged 5 days. This is to be contrasted with a halflife in normal subjects of $7 \mathrm{~h}$ (1). Renal clearance of urea in these subjects was very low, averaging 2.0 liters/ day, contrasted to a normal value of approximately 78 liters/day. Renal excretion of urea $\mathrm{N}$ averaged only $2.1 \mathrm{~g} /$ day, or about one-fifth of the usual value in normal subjects. Urea $\mathrm{N}$ appearance rate was even lower, $1.6 \mathrm{~g} /$ day, because the urea pool was generally decreasing. None of these values differed significantly between the two dietary regimens, because of considerable variability within each group.

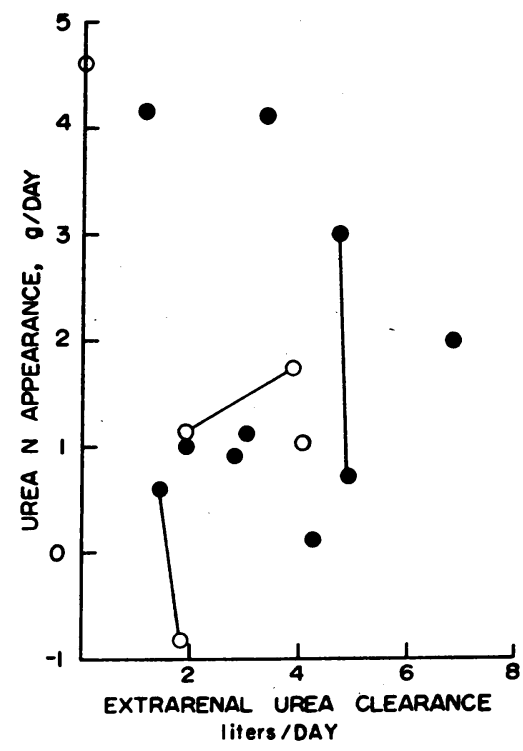

Figure 2 Relationships between urea $\mathrm{N}$ appearance and extrarenal urea clearance. If urea degradation promoted $\mathrm{N}$ conservation, a negative correlation might be expected. No correlation is seen, and repeated measurements (connected by lines) in three subjects reveal no correlation between changes in these, quantities. Open circles represent subjects receiving essential amino acids; solid circles represent subjects receiving their keto- or hydroxy-analogues.

Extrarenal clearance of urea in normal subjects averages about 18 liters/day $(1,2)$. In both groups of uremic patients, far lower values were observed (average $=3.1$ liters/day). But when this value is multiplied by mean plasma urea $\mathrm{N}$ concentration, $1.1 \mathrm{~g} /$ liter, the resulting rate of urea $\mathrm{N}$ degradation, $3.5 \mathrm{~g} / \mathrm{day}$, is close

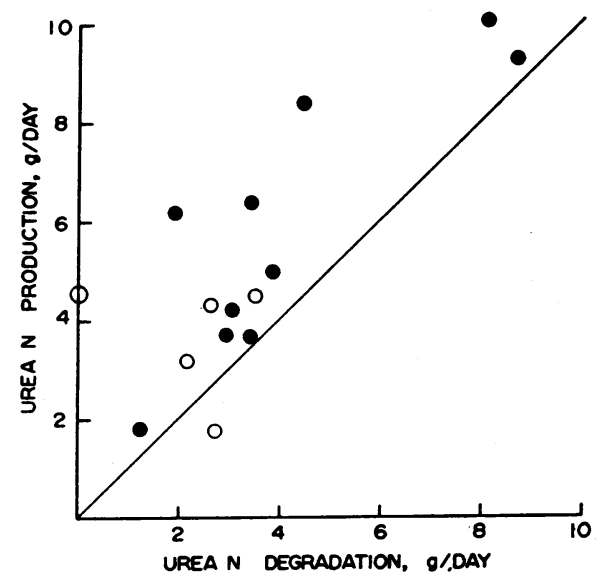

Figure 3 Relationship between urea production and urea degradation. Symbols as in Fig. 2. The diagonal line of identity is shown. The correlation is highly significant ( $r$ $=0.76, P<0.001$ ), suggesting that most of the $\mathrm{N}$ derived from urea degradation is converted back to urea rather than being used for protein synthesis.

Urea Metabolism in Chronic Uremia

1389 


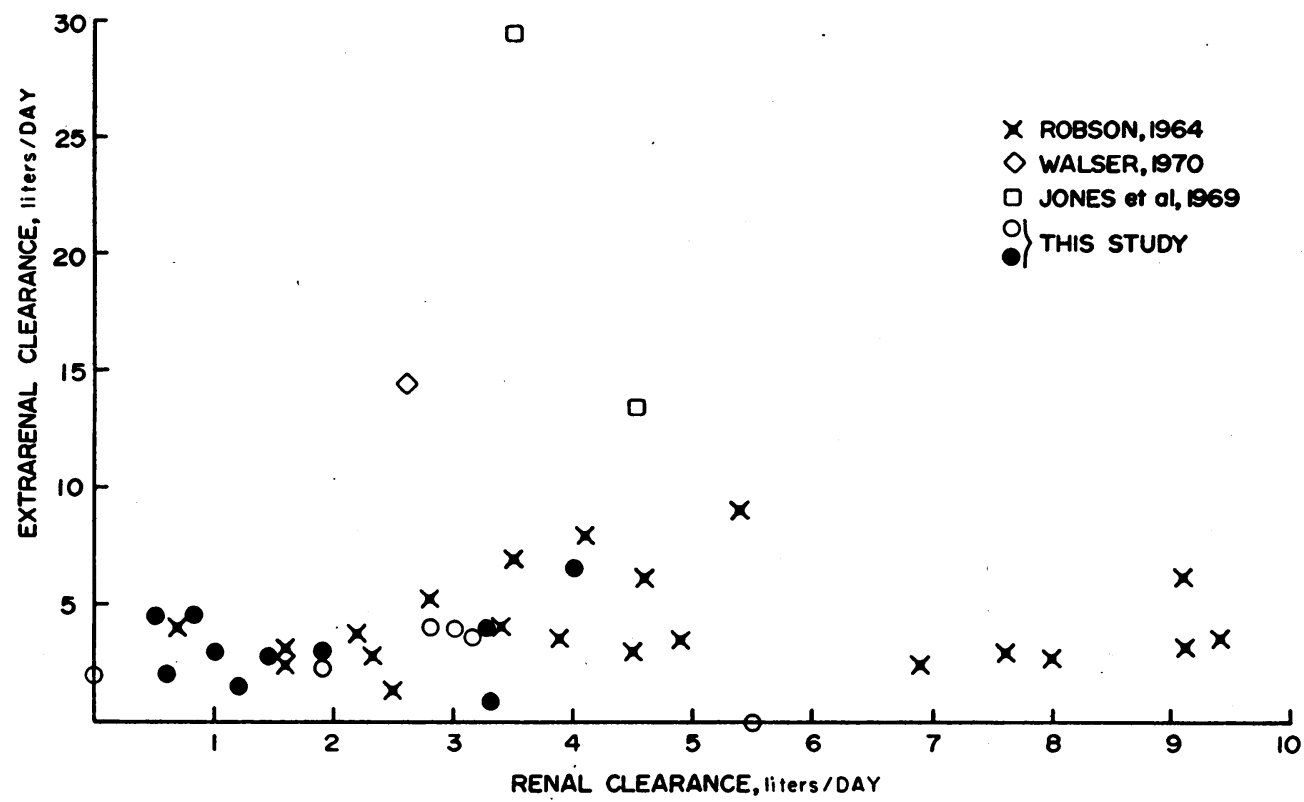

FIGURE 4 Summary of reported data on extrarenal vs. renal clearance of urea in chronic uremia. Symbols from this study are as in Figs. 2 and 3. Data from Robson (1964) are similar, but two observations by Jones et al. (1969) and one by Walser (1970) indicate far higher rates of extrarenal clearance, similar to those reported in normal persons.

to the reported normal value, $4 \mathrm{~g} /$ day $(1,2)$. Thus, in these patients, urea is being broken down at a normal rate, in absolute terms. There is in fact no significant correlation in these data between urea degradation and plasma urea concentration $(r=0.45, P>0.05)$.

Urea degradation as a fraction of urea production averaged $70 \%$, far greater than normal, as has been noted previously $(2,5)$. This fraction gives a somewhat misleading impression of the magnitude of urea degradation, since degradation is not in fact increased in these subjects when measured in absolute terms or in relation to plasma urea concentration.

The results were examined to determine whether low values of urea appearance, which is a desirable clinical goal, are correlated with high or low values of extrarenal clearance or urea degradation. As shown in Fig. 2 , there was no correlation between urea appearance and extrarenal clearance. Furthermore, repeated measurements (in three subjects) showed no consistent relationship between spontaneous changes in urea degradation and the rate of urea appearance. The correlation between urea appearance and urea degradation was also insignificant $(r=-0.22, P>0.1)$.

However, urea production was highly correlated with urea degradation $(r=0.76, P<0.001)$ as shown in Fig. 3.

\section{DISCUSSION}

Urea degradation in uremic patients has long been held to be increased (2-11). When data on which this inference is based are examined carefully, it is by no means apparent that such is the case. In the first such study (5), urea degradation as a fraction of urea production was shown as a function of plasma urea concentration, and in addition, absolute values of urea production were reported. These data do not allow calculation of extratenal clearances or degradation rate. Robson's thesis (4) gives more complete data, and indicates an average extrarenal clearance of urea of 4.5 liters/day, similar to the values found in the present study.

Deane, Desir, and Umeda (6) used $\left[{ }^{14} \mathrm{C}\right]$ urea to measure ureolysis in uremic patients pretreated with oral neomycin. Samples were obtained from 2 to $7 \mathrm{~h}$ after injection. Since the slope averaged $0.012 / \mathrm{h}$ the plasma radioactivity declined only about $6 \%$ during the period of observation. Accurate measurements of exponential decay under these conditions are difficult if not impossible.

Jones et al. (2) studied two uremic subjects not on antibiotics. Extrarenal clearances averaged 21 liters/ day and degradation averaged $15.5 \mathrm{~g} /$ day. Samples were obtained between $2 \frac{1}{2}$ and $12 \mathrm{~h}$ after injection, cor-

\section{$1390 \quad$ M. Walser}


responding to a fall of approximately $25 \%$ in blood radioactivity.

Walser (8) studied one uremic patient using ${ }^{15} \mathrm{~N}$-labeled urea and correcting for reincorporation of label. Extrarenal clearance was 14 liters/day and degradation $17 \mathrm{~g} \mathrm{~N} /$ day.

As shown in Fig. 4, these three observations are far removed from the data of the present study and those of Robson (4).

Several possible explanations of these discrepancies deserve consideration. The patients in the present study all received essential amino acids or their analogues, whereas the patients in the previous studies received low protein diets alone. This cannot be the explanation of the difference, because Robson's $(4,5)$ subjects were also on protein restriction alone.

$\left[{ }^{15} \mathrm{~N}\right]$ Urea was used in the study I reported previously (8). It is possible that analytical errors may have occurred that are peculiar to the use of this isotope. However, $\left[{ }^{15} \mathrm{~N}\right]$ urea and $\left[{ }^{14} \mathrm{C}\right]$ urea give similar results if allowances are made for the reutilization of ${ }^{15} \mathrm{~N}$ derived from $\left[{ }^{15} \mathrm{~N}\right]$ urea breakdown (17).

By far the largest portion of the available data indicates that urea degradation in uremia is in fact close to normal, and that extrarenal urea clearance is therefore greatly reduced.

Several possible explanations may be considered. First, elevated plasma urea itself could cause a reduction in extrarenal clearance. This could reflect saturation of the enzyme or limitation in the rate of diffusion of urea to (or ammonia from) the enzyme surface. But if this were the case, extrarenal clearance of urea should be negatively correlated with plasma level. No such correlation is found in the data in this study or in Robson's (4) data. Furthermore, there is no basis for concentration dependence of a diffusion-limited system in the absence of a carrier. The absence of urea in fecal fluid of uremic patients (9) gives no clue as to the extent of urea hydrolysis that has occurred.

Second, high blood urea may alter bowel flora in such a way that urea-splitting enzyme activity is reduced. According to Brown, Hill, and Richards (18) the opposite is the case: chronic uremic patients exhibit increased urease activity in feces. Furthermore, the same negative correlation should be observed. Third, some other component of the chronic uremic state may reduce urea-splitting in the gut. This seems more consistent with the present data, but is more a description of the results than a mechanism.

The role of urea degradation in $\mathrm{N}$ balance is not established by these observations because the extent to which portal ammonia is used for protein synthesis is not revealed. However, the strong correlation ( $r=$ 0.76) between urea degradation and production (Fig.
3) suggests that a major portion of urea production is derived from portal ammonia. ${ }^{15} \mathrm{~N}$ incorporation data (3) do not give a reliable quantitative estimate because of the uncertain contribution of exchange reactions (19). A more elaborate technique, in which $\left[{ }^{15} \mathrm{~N}\right]$ labeled ammonia is administered by constant intragastric infusion and the distribution of singly and doubly labeled urea molecules $(20)$ is determined has recently been reported by Picou and Phillips (21), in preliminary form. This method has not yet been applied to uremia.

A simpler approach to this problem is a comparison of urea appearance rates before and after intestinal bacteriostasis. Clearly, a negative urea appearance rate must become positive when $M$ is eliminated, as shown by Eq. 4. A positive appearance rate could also increase if a substantial contribution of portal ammonia were thereby eliminated. The present data, however, fail to support the commonly held view that intestinal degradation of urea facilitates $\mathrm{N}$ conservation.

\section{ACKNOWLEDGMENTS}

This work was supported by U. S. Public Health Service Grants (AM 15603 and RR 35). Valerie Hammond and Sylvia Butler provided technical assistance.

\section{REFERENCES}

1. Walser, M., and L. J. Bodenlos. 1959. Urea metabolism in man. J. Clin. Invest. 38: 1617.

2. Jones, E. A., R. A. Smallwood, A. Craigie, and V. M. Rosenoer. 1969. The enterohepatic circulation of urea nitrogen. Clin. Sci. (Oxf.). $37: 825$.

3. Richards, P., A. Metcalfe-Gibson, E. E. Ward, O. Wrong, and B. J. Houghton. 1967. Utilisation of ammonia nitrogen for protein synthesis in man, and the effect of protein restriction and uraemia. Lancet. 2: 845.

4. Robson, A. M. 1964. Urea Metabolism in Chronic Renal Failure. Doctor of Medicine Thesis. University of Newcastle upon Tyne, England.

5. Robson, A. M., D. N. S. Kerr, and R. Ashcroft. 1968. Urea metabolism in chronic uraemia : effect of protein restriction, anabolic steroids, and antibiotics. In $\mathrm{Nu}$ trition and Renal Disease. G. M. Berlyne, editor. The Williams \& Wilkins Company, Baltimore. 71.

6. Deane, N., W. Desir, and T. Umeda. 1968. The production and extra-renal metabolism of urea in patients with chronic renal failure treated with diet and dialysis. In Dialysis and Renal Transplantation. Proceedings of the 4th Conference of the European Dialysis and Transplant Association. D. N. S. Kerr, editor. Excerpta Medica Foundation, New York. 245.

7. Scholz, A. 1968. Investigations on the distribution and turnover rate of ${ }^{14} \mathrm{C}$-urea and tritiated water in renal failure. In Dialysis and Renal Transplantation. Proceedings of the 4th Conference of the European Dialysis and Transplant Association. D. N. S. Kerr, editor. Excerpta Medica Foundation, New York. 240.

8. Walser, M. 1970. Use of isotopic urea to study the distribution and degradation of urea in man. In Urea and the Kidney. B. Schmidt-Nielsen, editor. Excerpta Medica Foundation, Publishers, Amsterdam. 421.

Urea Metabolism in Chronic Uremia 
9. Wrong, O. 1971. The role of the human colon in homeostasis. Sci. Basis Med. 192.

10. Richards, P. 1972. Nutritional potential of nitrogen recycling in man. Am. J. Clin. Nutr. $25: 615$.

11. Giordano, C. 1963. Use of exogenous and endogenous urea for protein synthesis in normal and uremic subjects. J. Lab. Clin. Med. 62: 231.

12. Walser, M., A. W. Coulter, S. Dighe, and F. R. Crantz. 1973. The effect of keto-analogues of essential amino acids in severe chronic uremia. J. Clin. Invest. 52: 678.

13. McFarlane, A. S. 1963. Measurement of synthesis rates of liver-produced plasma proteins. Biochem. J. 89: 277.

14. Rothschild, M. A., M. Oratz, D. Zimmon, S. S. Schreiber, I. Weiner, and A. Van Caneghem. 1969. Albumin synthesis in cirrhotic subjects with ascites studied with carbonate ${ }^{24} \mathrm{C}$. J. Clin. Invest. 48: 344.

15. Tavill, A. S., A. Craigie, and V. M. Rosenoer. 1968. The measurement of the synthetic rate of albumin in man. Clin. Sci. (Oxf.). 34: 1.
16. Halperin, M., and M. Walser. 1957. The reliability of estimated rates of production in simple turnover experiments. Arch. Biochem. Biophys. 70: 141.

17. Regoeczi, E., L. Irons, A. Koj, and A. S. McFarlane. 1965. Isotopic studies of urea metabolism in rabbits. Biochem. J. 95 : 521.

18. Brown, C. L., M. J. Hill, and P. Richards. 1971. Bacterial ureases in uraemic men. Lancet. 2: 406.

19. Jones, E. A., A. Craigie, A. Koj, and A. S. McFarlane. 1967. Ammonia nitrogen and protein synthesis. Lancet. 2: 989.

20. Walser, M., J. George, and L. J. Bodenlos. 1954. A1tered proportions of isotopes of molecular nitrogen as evidence for a monomolecular reaction. J. Chem. Phys. 22: 1146 .

21. Picou, D., and M. Phillips. 1972. Urea metabolism in malnourished and recovered children receiving a high or low protein diet. Am. J. Clin. Nutr. 25: 1261. 